Article

\title{
Marine Alkaloid 2,2-Bis(6-bromo-3-indolyl) Ethylamine and Its Synthetic Derivatives Inhibit Microbial Biofilms Formation and Disaggregate Developed Biofilms
}

\author{
Raffaella Campana ${ }^{1, *\left(\mathbb{D}, \text { Gianfranco Favi }^{2} \text { (D) Wally Baffone }\right.}{ }^{\mathbf{1}}$ and Simone Lucarini ${ }^{3, *(D)}$ \\ 1 Department of Biomolecular Science, Division of Toxicological, Hygiene and Environmental Science, \\ Via S. Chiara 27, University of Urbino Carlo Bo, 61029 Urbino, Italy; wally.baffone@uniurb.it \\ 2 Department of Biomolecular Science, Section of Organic Chemistry and Organic Natural Compounds, \\ University of Urbino Carlo Bo, Via I Maggetti 24, 61029 Urbino, Italy; gianfranco.favi@uniurb.it \\ 3 Department of Biomolecular Science, Division of Chemistry, Piazza del Rinascimento 6, \\ University of Urbino Carlo Bo, 61029 Urbino, Italy \\ * Correspondence: raffaella.campana@uniurb.it (R.C.); simone.lucarini@uniurb.it (S.L.); \\ Tel.: +39-0722-303543 (R.C.); +39-0722-303333 (S.L.)
}

Received: 20 December 2018; Accepted: 20 January 2019; Published: 23 January 2019

\begin{abstract}
The antimicrobial activity of the marine bisindole alkaloid 2,2-bis(6-bromo-3-indolyl) ethylamine (1) and related synthetic analogues (compounds 2-8) against target microorganisms was investigated by Minimum Inhibitory Concentration (MIC) determination. Compound 1 showed the greatest antimicrobial activity with the lowest MIC ( $8 \mathrm{mg} / \mathrm{L})$ against Escherichia coli, Staphylococcus aureus, and Klebsiella pneumoniae, while the derivatives exhibited higher MICs values (from 16 to $128 \mathrm{mg} / \mathrm{L}$ ). Compounds 1, 3, 4, and 8, the most active ones, were then tested against E. coli, S. aureus, K. pneumoniae, and Candida albicans during biofilms formation as well as on $24 \mathrm{~h}$ developed biofilms. The natural alkaloid 1 inhibited the biofilm formation of all the tested microorganisms up to 82.2\% and disaggregated biofilms of E. coli, S. aureus, K. pneumoniae, and C. albicans after 30 min of contact, as assessed by viable plate count and crystal violet (CV) staining (optical density at $570 \mathrm{~nm}$ ). Synthetic derivatives 3, 4, and 8 displayed anti-biofilm activity toward individual bacterial populations. This study highlights the potential of marine bisindole alkaloid $\mathbf{1}$ as anti-biofilm agent and shows, through a preliminary structure activity relationship (SAR), the importance of halogens and ethylamine side chain for the antimicrobial and antibiofilm activities of this bisindole series.
\end{abstract}

Keywords: marine bisindole alkaloids; bisindole derivatives; anti-biofilm activity

\section{Introduction}

Biofilms represent the predominant phenotype of most bacteria in their natural habitat. The biofilm formation requires a first phase of adhesion to the surface, after the cells start to replicate into micro-colonies and to produce an extracellular polymeric substance (EPS), composed of polysaccharides and other macromolecules [1,2]. The EPS plays an important role in biofilm because it helps the bond between the bacteria and the substratum and it protects the colonies from any environmental stress, including antimicrobial treatment [3]. Food surfaces as well as medical environments are suitable surfaces for microbial colonization and subsequently biofilm formation [4], thus representing a potential risk to transmit pathogens to humans by cross-contaminations. Moreover, biofilms that were developed on medical devices are difficult to eradicate due to the significant decrease in the susceptibility to antimicrobials of bacteria organized in biofilm, as compared to their planktonic form [5]. 
Marine natural products show potent activity and selectivity against a wide spectrum of pharmacological targets and their unprecedented structures are often an important source of lead compounds in drug discovery and development [6]. Among the various structural classes, the marine bisindole alkaloids, dimers of indole typically produced by marine sponges $[7,8]$, have received much attention due to their significant cytotoxicity, antineoplastic activity, as well as antimicrobial and antibiofilm activity [9-11]. Notably, 2,2-bis(6-bromo-3-indolyl)ethylamine (compound 1) (Figure 1), isolated from the Californian tunicate Didemnum candidum and the New Caledonian sponge Orina spp. [12,13], has shown antiplasmodial activity [14,15], cytotoxicity against several tumor cell lines, such as U937 human leukemia [16,17], MCF-7 human breast, and Caco-2 human epithelial colorectal [18]. Several natural and synthetic products with antibacterial and antibiofilm activity (tulongicin, turbomycin B, etc.) (Figure 1) share with compound 1, a common 3,3'-diindolylmethane (DIM) molecular unit [19-21].<smiles>NCC(c1c[nH]c2cc(Br)ccc12)c1c[nH]c2cc(Br)ccc12</smiles>

2,2-bis(6-bromo-3-indolyl) ethylamine (1)<smiles>CCCC(CCC)(c1c[nH]c2ccc(C3=NCCN3)cc12)c1c[nH]c2ccc(C3=NCCN3)cc12</smiles>

11

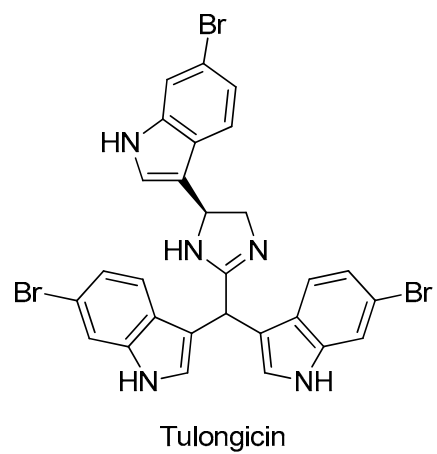

Tulongicin<smiles>c1ccc(C(c2c[nH]c3ccccc23)c2c[nH]c3ccccc23)cc1</smiles>

Turbomycin B<smiles>Brc1ccc(C(c2c[nH]c3ccc(Br)cc23)c2c[nH]c3ccc(Br)cc23)cc1</smiles>

12

Figure 1. The marine alkaloid 1, some natural and synthetic antibacterial agents having the 3,3'-diindolylmethane (DIM) molecular unit.

For example, tulongicin, derived from a Topsentia sp. marine sponge, is a bisindolemethane linked to an imidazole group that inhibited the growth of S. aureus [22]. Compound 11, which was developed by Dong and co-workers [23], showed to be very potent against several methicillin-resistant S. aureus clinical strains both in the planktonic and biofilm forms. However, to the best of our knowledge, no studies were devoted to the antimicrobial and antibiofilm abilities of $\mathbf{1}$ and analogues. Moreover, the presence of the alkylamino side chain in the marine alkaloid $\mathbf{1}$ could improve its solubility in water, possibly enhancing the antimicrobial and/or antibiofilm activity and allowing the possibility of further synthetic transformations by amino derivatization and/or conjugation.

For these reasons, in the present study, the marine bisindole alkaloid $\mathbf{1}$ and some related derivatives were synthesized (Figure 2) and tested against several target microorganisms, including Gram-postitive, Gram-negative, and mycetes, by Minimum Inhibitory Concentration (MIC) determination. The most active compounds were then tested for their anti-biofilm activity during biofilms formation as well as on developed biofilms. 


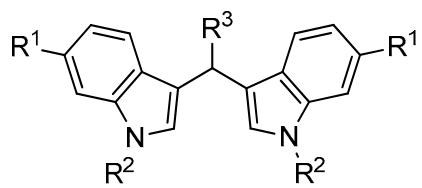

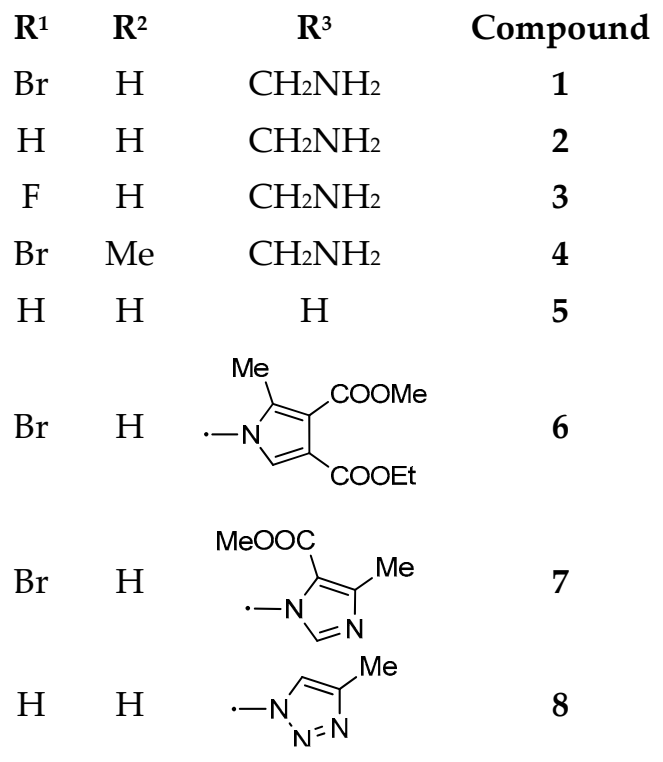

Figure 2. Marine bisindole alkaloid $\mathbf{1}$ and its synthetic derivatives 2-8.

\section{Materials and Methods}

\subsection{Chemicals}

Bis(1H-indol-3-yl)methane (compound 5) and all organic solvents that were used in this study were purchased from Sigma (Milan, Italy). Prior to use, acetonitrile was dried with molecular sieves with an effective pore diameter of $4 \AA$. Column chromatography purifications were performed under "flash" conditions using Merck 230-400 mesh silica gel. Analytical thin-layer chromatography (TLC) was carried out on Merck silica gel plates (silica gel 60 F254), which were visualized by exposure to ultraviolet light and an aqueous solution of cerium ammonium molybdate (CAM). ESI-MS spectra were recorded with a Waters Micromass ZQ spectrometer). EI-MS spectra were recorded with a Shimadzu QP-5000 Mass spectrometer. ${ }^{1} \mathrm{H}$ NMR and ${ }^{13} \mathrm{C}$ NMR spectra were recorded on a Bruker AC 400 or 100 , respectively, spectrometer and analyzed using the TopSpin software package. Chemical shifts were measured by using the central peak of the solvent.

\subsection{Chemistry}

Marine bisindole alkaloid 1 and compounds 2-4 were prepared, as described in Figure 3.<smiles></smiles><smiles>[10BH-]</smiles><smiles>[R][R]1cc([C@@H](CN)c2cn([R2])c3cc([R])ccc23)c2ccc([R])cc12</smiles>

$\begin{array}{ll}\mathrm{R}^{1}=\mathrm{Br}, \mathrm{R}^{2}=\mathrm{H} & \mathbf{1} \\ \mathrm{R}^{1}=\mathrm{H}, \mathrm{R}^{2}=\mathrm{H} & \mathbf{2} \\ \mathrm{R}^{1}=\mathrm{F}, \mathrm{R}^{2}=\mathrm{H} & \mathbf{3} \\ \mathrm{R}^{1}=\mathrm{Br}, \mathrm{R}^{2}=\mathrm{Me} & \mathbf{4}\end{array}$

Figure 3. Reaction conditions: (a) diphenyl phosphate, acetonitrile, $80^{\circ} \mathrm{C}, 24 \mathrm{~h}$; (b) $\mathrm{K}_{2} \mathrm{CO}_{3}$, methanol, reflux, $2 \mathrm{~h}$.

\subsubsection{General Procedure for the Synthesis of Derivatives 1-4}

Diphenyl phosphate $(0.02 \mathrm{mmol})$ was added to a solution of the appropriate indole derivative $(0.4 \mathrm{mmol})$ and (trifluoroacetylamino)acetaldehyde dimethyl acetal $(0.2 \mathrm{mmol})$ in anhydrous 
acetonitrile $(0.2 \mathrm{~mL})$, and the resulting mixture was stirred at $80^{\circ} \mathrm{C}$ for $24 \mathrm{~h}$ in a sealed tube, monitoring the progress of the reaction by TLC and HPLC-MS. After cooling to room temperature, saturated aqueous $\mathrm{NaHCO}_{3}(30 \mathrm{~mL})$ and dichloromethane $(30 \mathrm{~mL})$ were added and the two phases were then separated. The aqueous solution was extracted with dichloromethane $(3 \times 20 \mathrm{~mL})$. After drying over dry $\mathrm{Na}_{2} \mathrm{SO}_{4}$, the combined organic phases were concentrated in vacuum and the resulting crude product was utilized without further purification. A mixture of that crude trifluoroacetamide derivative and potassium carbonate $(1 \mathrm{mmol})$ in $\mathrm{MeOH}(1.87 \mathrm{~mL})$ and $\mathrm{H}_{2} \mathrm{O}(0.13 \mathrm{~mL})$ was stirred and heated at reflux for $2 \mathrm{~h}$. The $\mathrm{MeOH}$ was removed under reduced pressure and water was added $(30 \mathrm{~mL})$. The aqueous solution was extracted with dichloromethane $(3 \times 30 \mathrm{~mL})$ and the resulting solution was dried with $\mathrm{Na}_{2} \mathrm{SO}_{4}$ and then concentrated in vacuum. The crude material was purified by flash chromatography on neutral alumina.

\subsubsection{2,2-Bis(6-Bromo-1H-Indol-3-Yl) Ethylamine (1) and 2,2-Bis(1H-Indol-3-Yl) Ethylamine (2)}

The physico-chemical data of compounds $\mathbf{1}$ and $\mathbf{2}$ are in agreement with those that were reported [17].

\subsubsection{2,2-Bis(6-Fluoro-1H-Indol-3-Yl) Ethylamine (3)}

Compound 3 was prepared employing 6-fluoro- $1 H$-indole and was isolated by column chromatography (dichloromethane/methanol/triethylamine, 90:9:1) as a white solid in 70\% yield (two steps). TLC: $\mathrm{Rf}=0.18$ (silica gel; dichloromethane/ methanol/ triethylamine, 90:9:1; UV, CAM). MS (ESI): $m / z 310[\mathrm{M}-\mathrm{H}]^{-} .{ }^{1} \mathrm{H}$ NMR $\left(400 \mathrm{MHz}, \mathrm{CD}_{3} \mathrm{OD}, 293 \mathrm{~K}\right): \delta=3.37-3.41\left(\mathrm{~m}, 2 \mathrm{H}, \mathrm{CHCH}_{2} \mathrm{NH}_{2}\right)$, $4.52\left(\mathrm{dd}, 1 \mathrm{H}, J_{1}=J_{2}=7.5 \mathrm{~Hz}, \mathrm{CHCH}_{2} \mathrm{NH}_{2}\right), 6.72\left(\mathrm{ddd}, 2 \mathrm{H}, J_{5-7}=2.0 \mathrm{~Hz}, J_{5-4}=9.0 \mathrm{~Hz}, J_{5-\mathrm{F}}=9.5 \mathrm{~Hz}, \mathrm{H} 5\right)$, $7.04\left(\mathrm{dd}, 2 \mathrm{H}, J_{7-5}=2.0 \mathrm{~Hz}, J_{7-\mathrm{F}}=9.5 \mathrm{~Hz}, \mathrm{H} 7\right), 7.14(\mathrm{~d}, 2 \mathrm{H}, J=3.0 \mathrm{~Hz}, \mathrm{H} 2), 7.44\left(\mathrm{dd}, 2 \mathrm{H}, J_{4-\mathrm{F}}=5.0 \mathrm{~Hz}\right.$, $\left.J_{4-5}=9.0 \mathrm{~Hz}, \mathrm{H} 4\right)$ ppm. ${ }^{13} \mathrm{C} \mathrm{NMR}\left(100 \mathrm{MHz}, \mathrm{CD}_{3} \mathrm{OD}, 293 \mathrm{~K}\right): \delta=37.2,45.6,96.7(\mathrm{~d}, 2 \mathrm{C}, J=26 \mathrm{~Hz}, \mathrm{C} 5)$, $106.5(\mathrm{~d}, 2 \mathrm{C}, J=24 \mathrm{~Hz}, \mathrm{C} 7), 116.4(2 \mathrm{C}, \mathrm{C} 3), 119.5(\mathrm{~d}, 2 \mathrm{C}, J=10 \mathrm{~Hz}, \mathrm{C} 4), 122.3(\mathrm{~d}, 2 \mathrm{C}, J=3 \mathrm{~Hz}, \mathrm{C} 9), 123.6$ (2C, C2), $137.0(\mathrm{~d}, 2 \mathrm{C}, J=12 \mathrm{~Hz}, \mathrm{C} 8), 159.7$ (d, 2C, J = 233 Hz, C6) ppm.

\subsubsection{2,2-Bis(6-Bromo-1-Methyl-1H-Indol-3-Yl) Ethylamine (4)}

Compound 4 was prepared employing 6-bromo-1-methylindole and it was isolated by column chromatography (dichloromethane/ methanol/ triethylamine, 90:9:1) as yellowish solid (foam) in 77\% yield (two steps). TLC: $\mathrm{Rf}=0.22$ (silica gel; dichloromethane/ methanol/ triethylamine, 90:9:1; UV, CAM). MS (ESI): m/z 460 (50), 462 (100), 464 (50) [M + H] ${ }^{+} .{ }^{1} \mathrm{H}$ NMR (400 MHz, CD $\left.{ }_{3} \mathrm{OD}, 293 \mathrm{~K}\right):$ $\delta=3.32\left(\mathrm{~d}, 2 \mathrm{H}, J=7.5 \mathrm{~Hz}, \mathrm{CHCH}_{2} \mathrm{NH}_{2}\right), 3.72\left(\mathrm{~s}, 6 \mathrm{H}, \mathrm{NCH}_{3}\right), 4.49\left(\mathrm{dd}, 1 \mathrm{H}, J_{1}=J_{2}=7.5 \mathrm{~Hz}, \mathrm{CHCH}_{2} \mathrm{NH}_{2}\right)$, $7.06(\mathrm{~s}, 2 \mathrm{H}, \mathrm{ArH}), 7.06\left(\mathrm{dd}, 2 \mathrm{H}, J_{1}=1.5 \mathrm{~Hz}, J_{2}=8.5 \mathrm{~Hz}, \mathrm{ArH}\right), 7.40(\mathrm{~d}, 2 \mathrm{H}, J=8.5 \mathrm{~Hz}, \mathrm{ArH}), 7.51(\mathrm{~d}$, $2 \mathrm{H}, J=1.5 \mathrm{~Hz}, \mathrm{ArH}) \mathrm{ppm} .{ }^{13} \mathrm{C} \mathrm{NMR}\left(100 \mathrm{MHz}, \mathrm{CD}_{3} \mathrm{OD}, 293 \mathrm{~K}\right): \delta=31.4,36.8,45.8,112.0,114.7,115.9$, $120.2,121.4,126.3,127.2,138.2 \mathrm{ppm}$.

Compounds 6 and 7 were synthesized, as reported in Figure 4. 


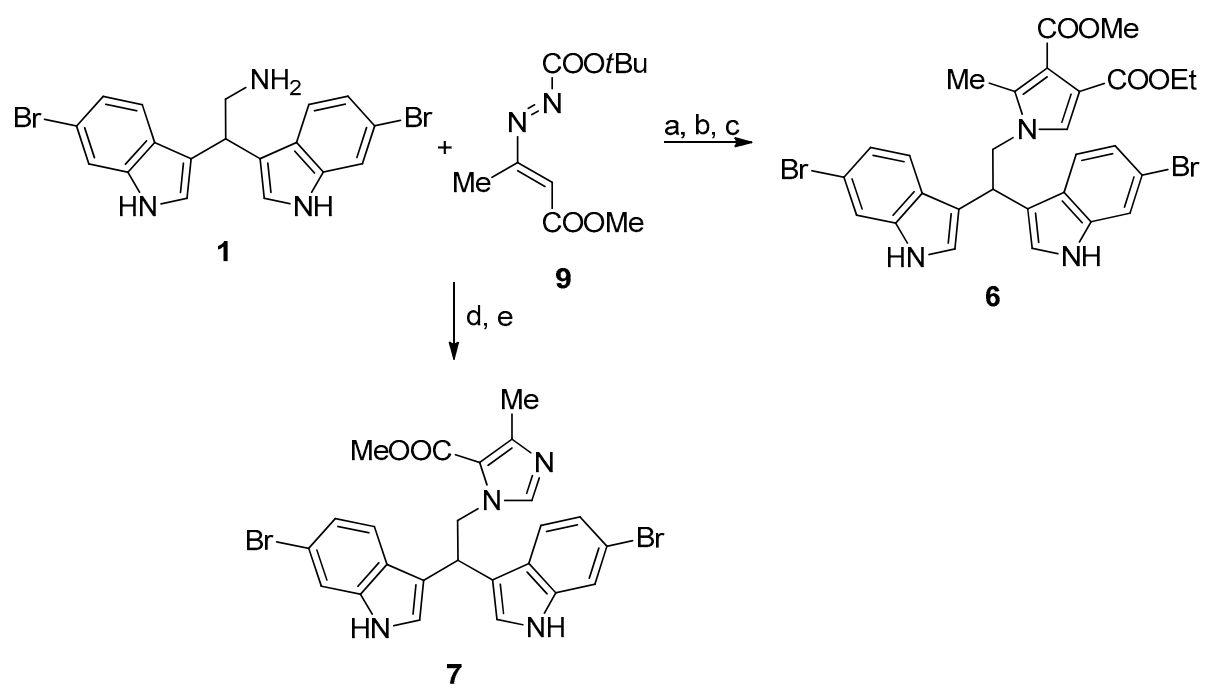

Figure 4. Reaction conditions: (a) ethyl propiolate, dichloromethane, at room temperature (RT), overnight (ON); (b) 9, toluene, reflux, 2 h; (c) trifluoroacetic acid, reflux, 4 h. (d) 9, acetonitrile, RT, 1 h; and, (e) paraformaldehyde, reflux, $4 \mathrm{~h}$.

2.2.5. 4-Ethyl 3-Methyl 1-(2,2-Bis(6-Bromo-1H-Indol-3-Yl)Ethyl)-2-Methyl-1H-Pyrrole-3,4Dicarboxylate (6)

A mixture of $1(0.4 \mathrm{mmol})$ and ethyl propiolate $(0.44 \mathrm{mmol})$ was stirred in dichloromethane $(1 \mathrm{~mL})$ overnight at room temperature. A solution of $9(0.6 \mathrm{mmol})$ in toluene $(4 \mathrm{~mL})$ was added and the reaction was refluxed for $2 \mathrm{~h}$. Catalytic amount of trifluoroacetic acid (two drops) was added and the reaction was refluxed for additional $4 \mathrm{~h}$. After removal of the solvent, the crude mixture was purified by column chromatography on silica gel (ethyl acetate/cyclohexane 25:75) to afford product 6 in $70 \%$ yield as a yellow solid. MS (EI) $m / z(\%)=627\left(\mathrm{M}^{+}\right)(3), 405(31), 403(100), 401(38) .{ }^{1} \mathrm{H}$ NMR $(400 \mathrm{MHz}$, DMSO-d6, $293 \mathrm{~K}): \delta=1.17\left(\mathrm{t}, 3 \mathrm{H}, J=7.2 \mathrm{~Hz}, \mathrm{OCH}_{2} \mathrm{CH}_{3}\right), 2.11\left(\mathrm{~s}, 3 \mathrm{H}, \mathrm{CH}_{3}\right), 3.64\left(\mathrm{~s}, 3 \mathrm{H}, \mathrm{OCH}_{3}\right), 4.06$ $\left(\mathrm{q}, J=7.2 \mathrm{~Hz}, 2 \mathrm{H}, \mathrm{OCH}_{2} \mathrm{CH}_{3}\right), 4.63\left(\mathrm{~d}, 2 \mathrm{H}, J=8.0 \mathrm{~Hz}, \mathrm{CHCH}_{2} \mathrm{~N}\right), 4.87\left(\mathrm{t}, 1 \mathrm{H}, J=8.0 \mathrm{~Hz}, \mathrm{CHCH}_{2} \mathrm{~N}\right)$, $6.99\left(\mathrm{dd}, 2 \mathrm{H}, J_{1}=1.6 \mathrm{~Hz}, J_{2}=8.8 \mathrm{~Hz}, \mathrm{ArH}\right), 7.16(\mathrm{~s}, 1 \mathrm{H}, \mathrm{ArH}), 7.37-7.42(\mathrm{~m}, 4 \mathrm{H}, \mathrm{ArH}), 7.49(\mathrm{~d}, 2 \mathrm{H}$, $J=1.6 \mathrm{~Hz}, \mathrm{Ar}-\mathrm{H}), 11.06$ (brs, 2H, NH). ${ }^{13} \mathrm{C}$ NMR $(100 \mathrm{MHz}, \mathrm{DMSO}-\mathrm{d} 6,293 \mathrm{~K}): \delta=10.7,14.6,35.2,50.9$, 51.4, 59.7, 100.0, 114.0, 114.2, 114.4, 115.4, 121.0, 121.6, 124.4, 125.8, 127.5, 135.3, 137.6, 163.7, 165.6.

\subsubsection{Methyl 1-(2,2-Bis(6-Bromo-1H-Indol-3-Yl)Ethyl)-4-Ethyl-1H-Imidazole-5-Carboxylate (7)}

To a stirred solution of $1(0.4 \mathrm{mmol})$ in acetonitrile $(2 \mathrm{~mL}), \mathbf{9}(0.4 \mathrm{mmol})$ was added at room temperature. After the disappearance of the reagents, paraformaldehyde $(0.8 \mathrm{mmol})$ was added, and then the resulting mixture was refluxed for $4 \mathrm{~h}$ (TLC check). The solvent was evaporated under reduced pressure and the crude residue was purified by column chromatography (ethyl acetate/cyclohexane 80:20) to give 7 as a brown solid in $72 \%$ yield. MS (EI) $m / z(\%)=556\left(\mathrm{M}^{+}\right)(100), 401(32), 403(100), 405$ (39). ${ }^{1} \mathrm{H}$ NMR (400 MHz, DMSO-d6, $\left.293 \mathrm{~K}\right): \delta=2.26\left(\mathrm{~s}, 3 \mathrm{H}, \mathrm{CH}_{3}\right), 3.80\left(\mathrm{~s}, 3 \mathrm{H}, \mathrm{OCH}_{3}\right), 4.91-4.96(\mathrm{~m}, 3 \mathrm{H}$, $\left.\mathrm{CHCH}_{2} \mathrm{~N}\right), 7.01\left(\mathrm{dd}, 2 \mathrm{H}, J_{1}=1.6 \mathrm{~Hz}, J_{2}=8.4 \mathrm{~Hz}, \mathrm{ArH}\right), 7.22(\mathrm{~s}, 1 \mathrm{H}, \mathrm{ArH}), 7.30(\mathrm{~d}, 2 \mathrm{H}, J=2.0 \mathrm{~Hz}, \mathrm{ArH})$, $7.40(\mathrm{~d}, 2 \mathrm{H}, J=8.4 \mathrm{~Hz}, \mathrm{ArH}), 7.50(\mathrm{~d}, 2 \mathrm{H}, J=1.6 \mathrm{~Hz}, \mathrm{ArH}), 11.04(\mathrm{brs}, 2 \mathrm{H}, \mathrm{NH}) .{ }^{13} \mathrm{C}$ NMR $(100 \mathrm{MHz}$, DMSO-d6, $293 \mathrm{~K}): \delta=16.1,35.4,51.0,51.8,114.2,114.5,115.4,117.9,120.8,121.6,124.4,125.9,137.6$, $142.2,147.4,161.5$.

Compound 8 was prepared as reported in Figure 5. 


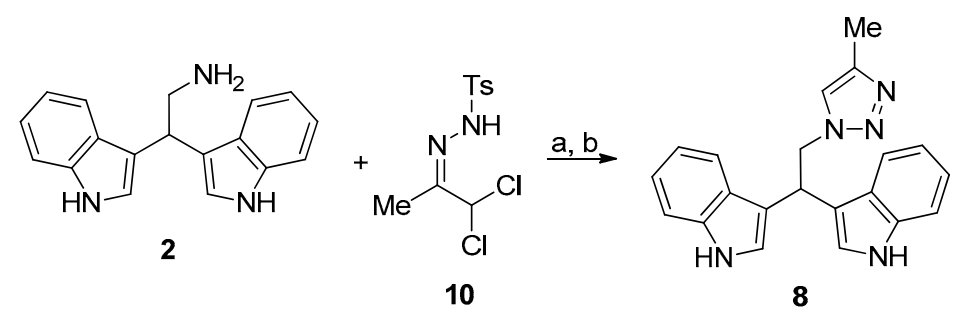

Figure 5. Reaction conditions: (a) $\mathrm{N}, \mathrm{N}$-diisopropylethylamine, ethanol, $0{ }^{\circ} \mathrm{C}, 10 \mathrm{~min}$; and, (b) 10, acetonitrile, $0^{\circ} \mathrm{C}, \mathrm{RT}, 2 \mathrm{~h}$.

\subsubsection{3,3'-(2-(4-Methyl-1H-1,2,3-Triazol-1-Yl)Ethane-1,1-Diyl)Bis(1H-Indole) (8)}

To a cooled solution $\left(0{ }^{\circ} \mathrm{C}\right)$ of $2 \quad(0.4 \mathrm{mmol})$ in ethanol $(5 \mathrm{~mL})$ was added $\mathrm{N}, \mathrm{N}$-diisopropylethylamine $(2.4 \mathrm{mmol}, 6 \mathrm{eq})$. The solution was stirred for $10 \mathrm{~min}$. after which hydrazone 10 ( $0.52 \mathrm{mmol}, 1.3$ eq.) dissolved in acetonitrile $(4 \mathrm{~mL})$ was added dropwise to the cooled solution and stirring was continued at room temperature until completion of the reaction (TLC check). After completion of the reaction, all volatiles were removed under reduced pressure and the residue was purified by column chromatography (ethyl acetate/cyclohexane 60:40) to give 8 as pale yellow solid in quantitative yield.

MS (EI) $m / z(\%)=341\left(\mathrm{M}^{+}\right)(4), 109(100) .{ }^{1} \mathrm{H}$ NMR $(400 \mathrm{MHz}$, DMSO-d6, $293 \mathrm{~K}): \delta=2.12(\mathrm{~s}, 3 \mathrm{H}$, $\left.\mathrm{CH}_{3}\right), 5.04-5.16\left(\mathrm{~m}, 3 \mathrm{H}, \mathrm{CH}_{2} \mathrm{CHN}\right), 6.91(\mathrm{t}, 2 \mathrm{H}, J=7.6 \mathrm{~Hz}, \mathrm{ArH}), 7.03(\mathrm{t}, 2 \mathrm{H}, J=7.6 \mathrm{~Hz}, \mathrm{ArH}), 7.31-7.35$ $(\mathrm{m}, 4 \mathrm{H}, \mathrm{ArH}), 7.54(\mathrm{~d}, 2 \mathrm{H}, J=8.0 \mathrm{~Hz}, \mathrm{ArH}), 7.68(\mathrm{~s}, 1 \mathrm{H}, \mathrm{ArH}), 10.86(\mathrm{brs}, 2 \mathrm{H}, \mathrm{NH}) ;{ }^{13} \mathrm{C} \mathrm{NMR}(100 \mathrm{MHz}$, DMSO-d6, 293 K): $\delta=10.9,35.5,53.9,111.9,115.3,118.7,119.2,121.4,122.8,123.2,126.8,136.8,141.7$.

\subsection{Bacterial Strains}

Six reference human pathogens were used in this study, Escherichia coli ATCC 35218, Pseudomonas aeruginosa ATCC 9027, Staphylococcus aureus ATCC 43387, Enterococcus faecalis ATCC 29212, and Candida albicans ATCC 14053. The clinical human strain Klebsiella pneumoniae 6/4, isolated from patient with urinary infection and kindly provided by Gamma Laboratory (Fano, Pesaro, Italy), was also included.

All of the strains were maintained in Tryptic Soy Agar (TSA, Oxoid, Milan, Italy) at $37^{\circ} \mathrm{C}$, while C. albicans ATCC 14053 was grown in Sabouraud Dextrose Agar (Oxoid, Milan, Italy). All the stock cultures were kept at $-80^{\circ} \mathrm{C}$ in Nutrient broth (Oxoid, Milan, Italy) with $15 \%$ of glycerol.

\subsection{Determination of Minimum Inhibitory Concentration (MIC)}

MICs were determined by standard micro-dilution method. First, each compound was dissolved in dimethyl sulfoxide (DMSO) (Sigma, Milan, Italy) of biological grade. Several colonies of each bacterial strain were inoculated in $10 \mathrm{~mL}$ of sterile Mueller-Hinton broth (MHB) (Oxoid) and incubated at $37^{\circ} \mathrm{C}$ for $18-24 \mathrm{~h}$. Each bacterial suspension was adjusted to about $10^{6} \mathrm{cfu} / \mathrm{mL}\left(\mathrm{OD}_{610 \mathrm{~nm}}\right.$ 0.13-0.15) and $100 \mu \mathrm{L}$ was added in wells of the 96-well cell culture plate (Cellstar ${ }^{\circledR}$, Greiner Bio-One, Frickenhausen, Germany), together with the appropriate volumes of the test solutions (from 0.5 to $128 \mu \mathrm{g} / \mathrm{mL}$ ). Two rows were used for positive (bacteria alone) and negative controls (MHB alone), respectively. Gentamicin (from 0.125 to $128 \mu \mathrm{g} / \mathrm{mL}$ ) and fluconazole (Sigma, Milan, Italy) were also added as internal controls. Preliminary assays with DMSO were carried out to exclude its possible bacteriostatic and/or bactericidal activity; the volume of DMSO added in each well never exceeded 5\% $(v / v)$ of the final total volume. The optical density $(600 \mathrm{~nm})$ of each well was assessed using a Multiscan Ex Microplate Reader (Thermo Scientific, Italy). MIC was defined as the lowest concentration of compound inhibiting the bacterial growth after $24 \mathrm{~h}$ of incubation. All data were expressed as the mean of three independent experiments that were performed in duplicate. 


\subsection{Crystal Violet Biofilm Assay}

A static biofilm formation assay was performed in 24-wells polystyrene plates (VWR, Milan, Italy) and biomass production was assessed after Cristal Violet (CV) staining, as described in Campana et al. [24]. All of the strains were grown in Tryptic Soy Broth (TSB, Oxoid, Milan, Italy) at $37^{\circ} \mathrm{C}$ for $24 \mathrm{~h}$ to obtain a bacterial suspension at the end of the logarithmic phase. Subsequently, the optical density of each suspension (OD $610 \mathrm{~nm}$ ) was adjusted to about $0.13-0.15$ (correspondent to $10^{6}-10^{7} \mathrm{cfu} / \mathrm{mL}$ ); $1 \mathrm{~mL}$ of each suspension, diluted 1:10 in TSB, was seeded in 24-well polystyrene plates $\left(\right.$ Cellstar ${ }^{\circledR}$, Greiner Bio-One, Frickenhausen, Germany), and incubated at $37^{\circ} \mathrm{C}$ for $24 \mathrm{~h}$ to allow biofilm formation. At the end of incubation, the wells were once washed with PBS to eliminate unattached cells and covered with crystal violet (CV) $0.1 \%(v / v)$ for $15 \mathrm{~min}$. The samples were once washed again with PBS and air-dried. The remaining CV was dissolved in $85 \%$ ethanol $(15 \mathrm{~min}$ at room temperature) and, finally, $200 \mu \mathrm{L}$ from each well was transferred to a 96-well cell culture plate $\left(\right.$ Cellstar $^{\circledR}$, Greiner Bio-One, Frickenhausen, Germany) for spectrophotometry at $570 \mathrm{~nm}$, using a Multiscan Ex Microplate Reader (Thermo Scientific). Each data point was averaged from at least eight replicate wells. The experiments were performed twice using independent cultures.

\subsection{Biofilm Formation Inhibition}

The anti-biofilm activity of each compound against each pathogen was determined in terms of biofilm formation inhibition. Briefly, $200 \mu \mathrm{L}$ of each bacterial suspension (about $10^{6}$ bacteria $/ \mathrm{mL}$ ) were inoculated in 24-well polystyrene plates (Cellstar ${ }^{\circledR}$, Greiner Bio-One, Frickenhausen, Germany) with the corresponding amount of each selected compound at their relative MIC and $2 \times$ MIC values. Two wells for each pathogen were also inoculated with bacteria in Tryptic Soy Broth (TSB) (Oxoid, Milan Italy) and included as controls. The plates were then incubated for $24 \mathrm{~h}$ at $37^{\circ} \mathrm{C}$ to allow biofilm development; at the end of the incubation, each sample was gently once washed by PBS and the biofilm formation inhibition for each pathogen was assessed by CV staining. All data were expressed as the mean of three independent experiments performed in duplicate.

\subsection{Eradication of Biofilms with Selected Chemical Compounds}

In these last experiments, the activity of selected compounds $(1,3,4$, and 8$)$ on developed biofilms of E. coli ATCC 35218, S. aureus ATCC 43387, K. pneumoniae 6/4, and C. albicans ATCC 10231 was determined. Briefly, biofilms of each pathogen were prepared with the procedure described above (Crystal violet biofilm assay section). After $24 \mathrm{~h}$ of incubation at $37^{\circ} \mathrm{C}$, all of the biofilms were gently once washed with PBS and covered for $30 \mathrm{~min}$ with the right amount of each compound corresponding to the MIC. For each plate, two wells were treated with physiological saline (negative controls). After antimicrobial treatment, all of the biofilms were once washed by PBS and adherent bacteria were harvested by sterile scrapers in $1 \mathrm{~mL}$ of sterile physiological saline solution, subsequently serially diluted in the same medium and plated in triplicate on TSA (Oxoid, Milan, Italy). The plates were then incubated at $37^{\circ} \mathrm{C}$ for $24 \mathrm{~h}$ at the end of which the colony forming units (cfu) were enumerated. To verify the eventual reduction of biomass production after antimicrobial treatment, CV staining was carried out as described above. All the data were expressed as the mean of three independent experiments performed in duplicate.

\subsection{Statistical Analysis}

Statistical analysis was performed using Prism version 5.0 (GraphPad Inc., La Jolla, CA, USA). The assumptions for parametric test were cheeked prior to carry out the statistical analysis by $t$-Student test. $p$ values $<0.05$ were considered to be statistically significant. 


\section{Results}

\subsection{Determination of Minimum Inhibitory Concentration}

The compound 1 showed the greatest antimicrobial activity against all the pathogens included in this study. In detail, the lowest MIC value of $8 \mu \mathrm{g} / \mathrm{mL}$ was observed for E. coli ATCC 35218, S. aureus ATCC 43387, and K. pneumoniae 6/4, while higher values were determined for E. faecalis ATCC 29212 $(32 \mu \mathrm{g} / \mathrm{mL})$, P. aeruginosa ATCC 9027, and C. albicans ATCC $10231(64 \mu \mathrm{g} / \mathrm{mL})$ (Table 1). As regards compound 3, the lowest MIC value $(64 \mu \mathrm{g} / \mathrm{mL})$ was evidenced for E. coli ATCC 35218 and $128 \mu \mathrm{g} / \mathrm{mL}$ for all others species. Compound 4 showed $16 \mu \mathrm{g} / \mathrm{mL}$ MIC value toward E. coli ATCC 35218 and $32 \mu \mathrm{g} / \mathrm{mL}$ against K. pneumoniae 6/4 and C. albicans ATCC 10231. MIC values of $128 \mu \mathrm{g} / \mathrm{mL}$ were registered for compound 8 , while all the other compounds showed MICs $>128 \mu \mathrm{g} / \mathrm{mL}$ for all the tested microorganisms. With regard to the internal control, gentamicin inhibited microbial growth with the lowest MIC value of $8 \mu \mathrm{g} / \mathrm{mL}$ for K. pneumoniae $6 / 4$ and the highest MIC value of $64 \mu \mathrm{g} / \mathrm{mL}$ for E. faecalis ATCC 29212 (Table 1). C. albicans ATCC 10231 resulted in being sensitive to fluconazole with MIC of $1 \mu \mathrm{g} / \mathrm{mL}$.

Table 1. Minimum Inhibitory Concentration (MIC) values $(\mu \mathrm{g} / \mathrm{mL})$ of the tested compounds against selected microbial strains, assessed by broth microdilution method according to the Performance Standards for Antimicrobial Susceptibility Testing (CLSI Document M100-S2, 2013). Gentamicin and fluconazole were used as internal controls.

\begin{tabular}{cccccccccc}
\hline Microbial Strains & $\mathbf{1}$ & $\mathbf{2}$ & $\mathbf{3}$ & $\mathbf{4}$ & $\mathbf{5}$ & $\mathbf{6}$ & $\mathbf{7}$ & $\mathbf{8}$ & Gentamicin \\
\hline E. coli ATCC 35218 & 8 & $>128$ & 64 & 16 & $>128$ & $>128$ & $>128$ & 128 & 16 \\
S. aureus ATCC 43387 & 8 & $>128$ & 128 & 128 & $>128$ & $>128$ & $>128$ & 128 & 16 \\
E. faecalis ATCC 29212 & 32 & $>128$ & 128 & 128 & $>128$ & $>128$ & $>128$ & 128 & 64 \\
P. aeruginosa ATCC 9027 & 64 & $>128$ & 128 & 128 & $>128$ & $>128$ & $>128$ & 128 & 16 \\
K. pneumoniae 6/4 & 8 & $>128$ & 128 & 32 & $>128$ & $>128$ & $>128$ & 128 & 8 \\
C. albicans ATCC 10231 & 64 & $>128$ & 128 & 32 & $>128$ & $>128$ & $>128$ & 128 & $1^{\text {a }}$ \\
\hline
\end{tabular}

${ }^{a}$ Fluconazole was used as control for C. albicans ATCC 10231.

\subsection{Biofilm Formation Inhibition}

The compounds 1, 3, 4, and 8 were tested at the relative MIC and $2 \times$ MIC values during the biofilm formation of the examined pathogens (Table 2). In many cases, the compounds at their relative MIC and $2 \times$ MIC values determined the bactericidal effect after $24 \mathrm{~h}$ of incubation (no visible growth in the wells) and, in these cases biofilm formation after CV staining were not assessed (Figure S1). E. faecalis ATCC 29212 and P. aeruginosa ATCC 9027 were not included on the basis of the results that were obtained during the biofilm formation, where E. faecalis resulted in being completely inhibited by all the tested compounds (bactericidal effect) while P. aeruginosa was resistant.

As general trend, compound 1 was able to reduce biofilm formation of most the examined bacteria at their relative MIC values, with the only exception of P. aeruginosa ATCC 9027. The lowest concentration $(8 \mu \mathrm{g} / \mathrm{mL})$, tested against E. coli ATCC 35218 and S. aureus ATCC 43387, provoked 68.3 and $82.2 \%$ of biofilm formation inhibition, respectively; the same concentration induced only $40.0 \%$ of $K$. pneumoniae $6 / 4$ biofilm formation inhibition, reaching $83.7 \%$ of inhibition with $16 \mu \mathrm{g} / \mathrm{mL}$ ( $2 \times$ MIC value). The highest concentration $(64 \mu \mathrm{g} / \mathrm{mL})$ was unable to inhibit the biofilm formation of P. aeruginosa ATCC 9027, while it exhibited bactericidal action against C. albicans ATCC 10231. The compound 3 (MIC $64 \mu \mathrm{g} / \mathrm{mL}$ ) was able to strongly inhibit the biofilm formation of E. coli ATCC $35218(97.6 \%)$. The highest MIC value $(128 \mu \mathrm{g} / \mathrm{mL})$ determined only $34.6 \%$ of biofilm formation inhibition in C. albicans ATCC 10231 and it was unable to contrast the biofilm formation of P. aeruginosa ATCC 9027 (7.8\%). On the other hand, $128 \mu \mathrm{g} / \mathrm{mL}$ resulted in being bactericidal against S. aureus ATCC 43387, E. faecalis ATCC 29212, and K. pneumoniae 6/4. The compound 4 was tested at MIC values ranging from 16 to $128 \mu \mathrm{g} / \mathrm{mL}$. The lowest concentration was bactericidal against E. faecalis 
ATCC 29212, while the biofilm formation of K. pneumoniae 6/4 was remarkably inhibited (64.7\%) by MIC value of $32 \mu \mathrm{g} / \mathrm{mL}$, reaching $96.6 \%$ of inhibition with $64 \mu \mathrm{g} / \mathrm{mL}$ ( $2 \times$ MIC value). Less biofilm inhibition (14.6\%) was observed for C. albicans ATCC 10231, with $32 \mu \mathrm{g} / \mathrm{mL}$, and also with $2 \times$ MIC value $(40.9 \%)$. The highest concentration of compound $4(128 \mu \mathrm{g} / \mathrm{mL})$ caused $56.6 \%$ of $S$. aureus ATCC 43387 biofilm formation inhibition and resulted in being bactericidal against $E$. faecalis ATCC 29212. As regards compound 8 (MIC $128 \mu \mathrm{g} / \mathrm{mL}$ ), remarkable biofilm formation inhibition was evidenced for K. pneumoniae 6/4 (65.8\%), while lower percentages were observed for E. coli ATCC $35218(54.1 \%)$ and S. aureus ATCC 43387 (34.9\%); also, in this case, the biofilm formation of P. aeruginosa ATCC 9027 was not reduced, while a bactericidal effect was observed against E. faecalis ATCC 29212 and C. albicans ATCC 10231. Increased percentages of biofilm formation inhibition were always observed with compound 8 at $2 \times$ MIC value.

Table 2. Biofilm formation inhibition exerted by compounds 1, 3, 4, and $\mathbf{8}$. Each molecule was added at its relative MIC and $2 \times$ MIC $(\mu \mathrm{g} / \mathrm{mL})$ values during the biofilm formation of the different pathogens; the inhibition percentages were determined after spectrophotometer reader at $570 \mathrm{~nm}$.

\begin{tabular}{|c|c|c|c|c|c|c|c|c|c|c|c|c|}
\hline \multirow{3}{*}{ Microbial Strains } & \multicolumn{3}{|c|}{1} & \multicolumn{3}{|c|}{3} & \multicolumn{3}{|c|}{4} & \multicolumn{3}{|c|}{8} \\
\hline & \multicolumn{4}{|c|}{$\begin{array}{c}\text { Biofilm } \\
\text { Inhibition }\end{array}$} & \multicolumn{2}{|c|}{$\begin{array}{c}\text { Biofilm } \\
\text { Inhibition }\end{array}$} & \multicolumn{4}{|c|}{$\begin{array}{c}\text { Biofilm } \\
\text { Inhibition }\end{array}$} & \multicolumn{2}{|c|}{$\begin{array}{c}\text { Biofilm } \\
\text { Inhibition }\end{array}$} \\
\hline & MIC & MIC & $2 \times \mathrm{MIC}$ & MIC & MIC & $2 \times$ MIC & MIC & MIC & $2 \times \mathrm{MIC}$ & MIC & MIC & $2 \times \mathrm{MIC}$ \\
\hline E. coli ATCC 35218 & 8 & $68.3 \%$ & $\mathrm{BE}$ & 64 & $97.6 \%$ & $\mathrm{BE}$ & 16 & $1.7 \%$ & $48.1 \%$ & 128 & $54.1 \%$ & $92.0 \%$ \\
\hline S. aureus ATCC 43387 & 8 & $82.2 \%$ & BE & 128 & BE & ND & 128 & $56.6 \%$ & BE & 128 & $34.9 \%$ & $62.9 \%$ \\
\hline E. faecalis ATCC 29212 & 32 & $\mathrm{BE}$ & ND & 128 & $\mathrm{BE}$ & ND & 128 & $\mathrm{BE}$ & ND & 128 & $\mathrm{BE}$ & ND \\
\hline P. aeruginosa ATCC 9027 & 64 & $0.5 \%$ & $0.9 \%$ & 128 & $7.8 \%$ & $\mathrm{BE}$ & 128 & $4.8 \%$ & $\mathrm{BE}$ & 128 & $7.1 \%$ & $\mathrm{BE}$ \\
\hline K. pneumoniae 6/4 & $\begin{array}{c}0+ \\
8\end{array}$ & $40.0 \%$ & $83.7 \%$ & 128 & $\mathrm{BE}$ & ND & 32 & $64.7 \%$ & $96.6 \%$ & 128 & $65.8 \%$ & $98.7 \%$ \\
\hline C. albicans ATCC 10231 & 64 & $\mathrm{BE}$ & ND & 128 & $34.6 \%$ & $\mathrm{BE}$ & 32 & $14.6 \%$ & $40.9 \%$ & 128 & $\mathrm{BE}$ & ND \\
\hline
\end{tabular}

BE, bactericidal effect: biomass was not determined by spectrophotometer reader $(570 \mathrm{~nm})$ because no bacterial growth was visible. in the wells (see also Figure S1); ND: not determined because already bactericidal at MIC value.

\subsection{Eradication of Biofilms after Treatment with Compounds 1, 3, $\mathbf{4}$ and $\mathbf{8}$}

In the case of E. coli ATCC 35218, the treatment of biofilms with compound 1 (MIC $8 \mu \mathrm{g} / \mathrm{mL}$ ) reduced bacterial viability to $2.0 \times 10^{7} \mathrm{cfu} / \mathrm{mL}$ in comparison to $5.28 \times 10^{8} \mathrm{cfu} / \mathrm{mL}$ of the relative control biofilm $(p<0.05)$, while the other compounds caused no significant reduction of $\mathrm{cfu} / \mathrm{mL}$ (Figure 6). For S. aureus ATCC 43387, compound 1 (MIC $8 \mu \mathrm{g} / \mathrm{mL}$ ) reduced viable bacteria to $2.27 \times 10^{6} \mathrm{cfu} / \mathrm{mL}$ in comparison to $3.85 \times 10^{8} \mathrm{cfu} / \mathrm{mL}$ of the untreated control $(p<0.001)$ and a statistical significant reduction in $\mathrm{cfu} / \mathrm{mL}$ values was also observed after treatment with compounds 4 (MIC $128 \mu \mathrm{g} / \mathrm{mL})(p<0.01)$. As regards K. pneumoniae 6/4, the treatment with compounds 1 (MIC $8 \mu \mathrm{g} / \mathrm{mL}$ ) and 4 (MIC $32 \mu \mathrm{g} / \mathrm{mL}$ ) determined values of $1.0 \times 10^{7}$ and $1.37 \times 10^{6} \mathrm{cfu} / \mathrm{mL}$, respectively, with a significant decrease in comparison to the relative control biofilm $\left(3.2 \times 10^{7} \mathrm{cfu} / \mathrm{mL}\right)(p<0.01$; $p<0.05$ ). No remarkable reduction of K. pneumoniae $6 / 4$ growth was observed with compounds 3 and 8 (MIC $128 \mu \mathrm{g} / \mathrm{mL}$ ). In the case of C. albicans ATCC 10231, the most remarkable decrease of cfu/mL was observed after the treatment with compound 1 (MIC $64 \mu \mathrm{g} / \mathrm{mL}$ ), showing $2.0 \times 10^{4} \mathrm{cfu} / \mathrm{mL}$ in comparison to $2.6 \times 10^{7} \mathrm{cfu} / \mathrm{mL}$ of the control one $(p<0.001)$. Similarly, the treatment with compounds $4\left(\right.$ MIC $32 \mu \mathrm{g} / \mathrm{mL}$ ) evidenced $3.0 \times 10^{4} \mathrm{cfu} / \mathrm{mL}(p<0.01)$, while compounds 3 and 8 (MICs $128 \mu \mathrm{g} / \mathrm{mL}$ ) induced only a slight reduction.

The biomass analysis revealed different decreases of $\mathrm{OD}_{570 \mathrm{~nm}}$ values in biofilms after treatment with the different compounds (Figure 7). As regards E. coli ATCC 35218, after exposure to compound 1 (MIC $8 \mu \mathrm{g} / \mathrm{mL}$ ), an OD of 0.320 was observed in comparison to 0.641 of the relative untreated biofilm $(p<0.01$ ), while the treatment with compounds 3 (MIC $64 \mu \mathrm{g} / \mathrm{mL}$ ), 4 (MIC $16 \mu \mathrm{g} / \mathrm{mL}$ ), and 8 (MIC $128 \mu \mathrm{g} / \mathrm{mL}$ ) showed OD values that were quite similar (from 0.541 to 0.622 ) to that of the control. The exposure of $S$. aureus ATCC 43387 biofilms to compound 1 (MIC $8 \mu \mathrm{g} / \mathrm{mL}$ ) determined an OD of 0.250 in comparison to 0.573 of the relative untreated biofilm $(p<0.01)$, while after treatment with compounds 3 and 4 (MICs $128 \mu \mathrm{g} / \mathrm{mL}$ ), OD values of 0.350 and 0.264 , respectively $(p<0.05)$ were 
registered. On the contrary, compound 8 (MIC $128 \mu \mathrm{g} / \mathrm{mL}$ ) determined an OD value quite similar to that of the relative control.

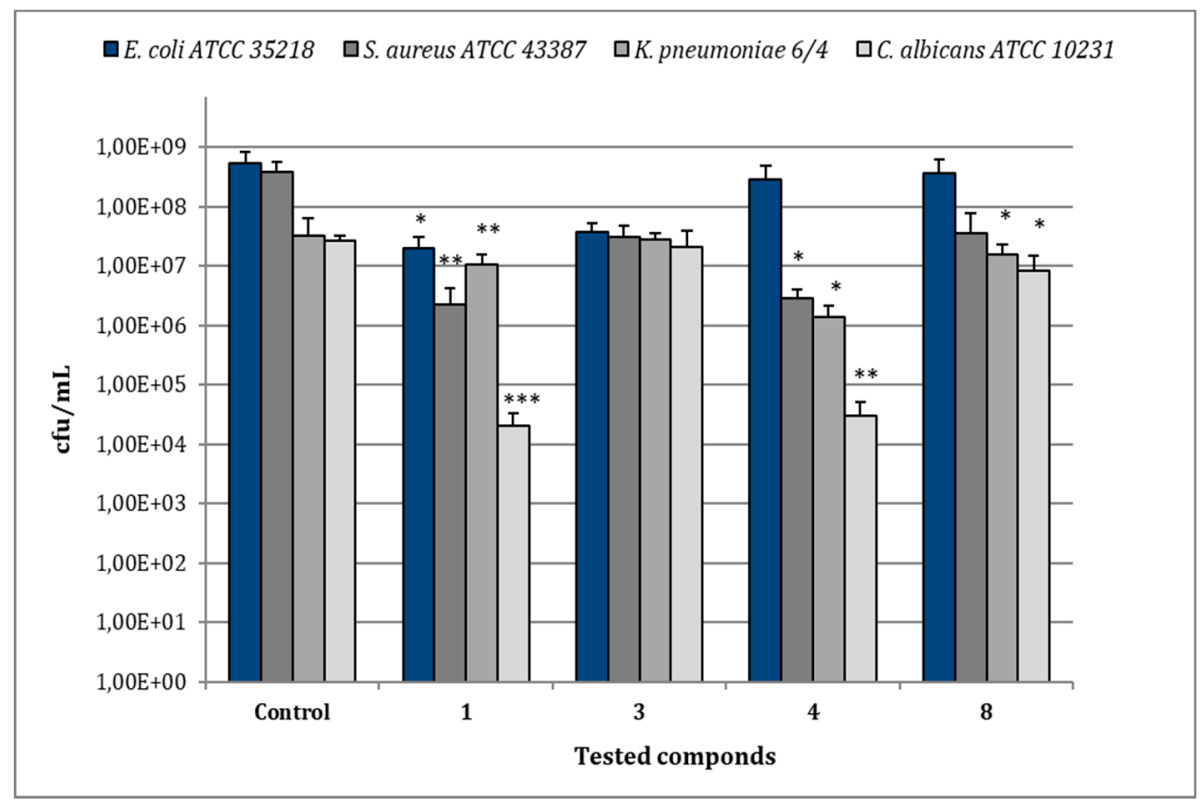

Figure 6. Assessment of viable cells harvested from biofilms of E. coli ATCC 35218, S. aureus ATCC 43387, K. pneumoniae 6/4 and C. albicans ATCC 10231 after 30 min of treatment with compounds 1, 3, 4, and 8 at their relative MIC values. Data represent the mean $\pm \mathrm{SD}$ of $\mathrm{cfu} / \mathrm{mL}$ values obtained in three independent experiments performed in duplicate. Asterisks represent values statistically significant (* $\left.p<0.05 ;{ }^{* *} p<0.01 ;{ }^{* * *} p<0.001\right)$ as compared to the related controls.

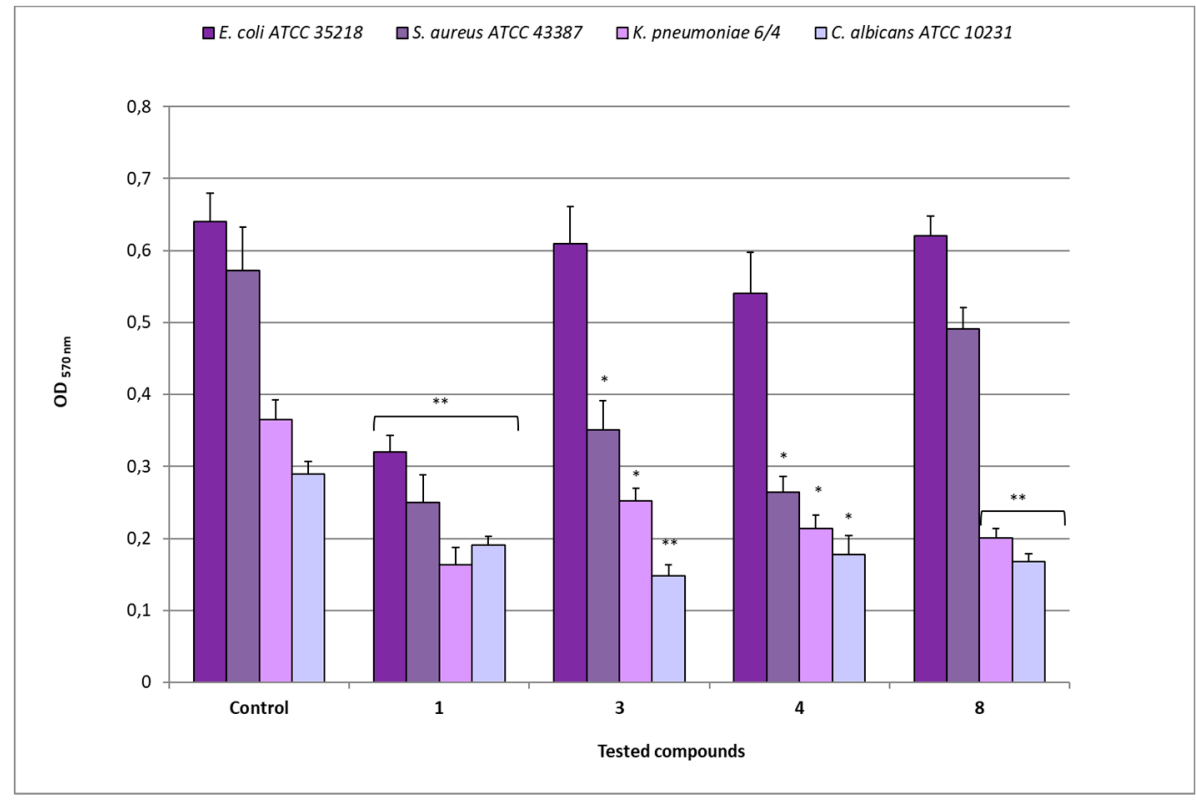

Figure 7. Disaggregating efficacy of compounds 1, 3, 4, and 8 at their relative MIC values, against biofilms of E. coli ATCC 35218, S. aureus ATCC 43387, K. pneumoniae 6/4 and C. albicans ATCC 10231, as assessed by spectrophotometer reader ( $\mathrm{OD}_{570 \mathrm{~nm}}$ ) after $30 \mathrm{~min}$ of contact. Data represent the mean $\pm \mathrm{SD}$ obtained in three independent experiments performed in duplicate. Asterisks represent values statistically significant $\left({ }^{*} p<0.05 ;{ }^{* *} p<0.01\right)$ as compared to the related controls.

For K. pneumoniae 6/4, compound 1 (MIC $8 \mu \mathrm{g} / \mathrm{mL}$ ) determined an OD of 0.163 in comparison to 0.365 of the relative untreated biofilm $(p<0.01)$, while the treatment with compounds 3 (MIC 
$128 \mu \mathrm{g} / \mathrm{mL}$ ), 4 (MIC $32 \mu \mathrm{g} / \mathrm{mL}$ ), and 8 (MIC $128 \mu \mathrm{g} / \mathrm{mL}$ ) induced 0.252, $0.214(p>0.05$ ), and 0.201 $(p<0.01)$ OD values, respectively. In the case of $C$. albicans ATCC 10231, the treatment with compound 1 (MIC $64 \mu \mathrm{g} / \mathrm{mL}$ ) reduced the biomass to OD 0.191 in comparison to 0.290 of the control one $(p<0.01$ ); similarly, after exposure to compounds 3 (MIC $128 \mu \mathrm{g} / \mathrm{mL}$ ), 4 (MIC $32 \mu \mathrm{g} / \mathrm{mL}$ ), and 8 (MIC $128 \mu \mathrm{g} / \mathrm{mL}$ ), OD values of $0.148(p<0.01), 0.178(p<0.05)$ and $0.168(p<0.01)$, respectively, were registered.

In Table 3 are summarized the percentages of biomass reduction, index of eradication activity, induced by each compound against the tested developed biofilms. As shown, after $30 \mathrm{~min}$ of contact with compound 1, reductions greater than $50 \%$ were observed for most of the examined strains, with the exception of C. albicans ATCC 10231 (only 34.2\%). On the contrary, all the derivatives (3, 4, and 8) showed low activity against E. coli ATCC 35218 biofilms, in some cases, also the derivatives reached remarkable percentages of biomass reduction. Interestingly, compound 3 reduced biofilm of $C$. albicans ATCC 10231 (48.8\%), resulting the most active compound against mycete biofilms. Compound 4 showed strong anti-biofilm activity against $S$. aureus ATCC 43387 with percentage comparable to compound 1 (53.9\% vs $56.3 \%$ ), while compound 8 acted as good disaggregating agent on K. pneumoniae 6/4 (44.9\%) and C. albicans ATCC 10231 (41.9\%) biofilms.

Table 3. Percentages of biofilm eradication activity assessed for E. coli ATCC 35218, S. aureus ATCC 43387, K. pneumoniae 6/4 and C. albicans ATCC 10231 after $30 \mathrm{~min}$ of contact with compounds 1, 3, 4, and 8 at their relative MIC $(\mu \mathrm{g} / \mathrm{mL})$ values. Percentages were determined after spectrophotometer reader $\left(\mathrm{OD}_{570 \mathrm{~nm}}\right)$.

\begin{tabular}{ccccc}
\hline Preformed Biofilms & $\mathbf{1}$ & $\mathbf{3}$ & $\mathbf{4}$ & $\mathbf{8}$ \\
\hline E. coli ATCC 35218 & $50.0 \%$ & $4.7 \%$ & $15.7 \%$ & $3.1 \%$ \\
S. aureus ATCC 43387 & $56.3 \%$ & $38.9 \%$ & $53.9 \%$ & $14.2 \%$ \\
K. pneumoniae 6/4 & $55.3 \%$ & $30.9 \%$ & $41.3 \%$ & $44.9 \%$ \\
C. albicans ATCC 10231 & $34.2 \%$ & $48.8 \%$ & $38.6 \%$ & $41.9 \%$ \\
\hline
\end{tabular}

\section{Discussion}

Currently, the research is being conducted to discover novel compounds that are able to inhibit microbial biofilms, without allowing bacteria to develop drug resistance. Marine invertebrates have been proved to be a rich source of bioactive compounds with different ecological functions $[6,25]$. Among these, sponges are marine sessile filters exposed to large amounts of bacteria in the surrounding seawater and their potential antimicrobial activity attracted the attention of many researchers $[10,26,27]$.

In the present study, the antimicrobial activity of $\mathbf{1}$ and its synthetic derivatives 2-8 was investigated (Table 1). The synthesis of heterocyclic compounds 1-4 and 6-8 was carried out according to literature procedures $[16,18]$. Regarding the preliminary SAR, our data evidenced that MICs of compound 1 resulted in being lower (from 8 to $64 \mu \mathrm{g} / \mathrm{mL}$ ) as compared to those of its derivatives (from 16 to $128 \mu \mathrm{g} / \mathrm{mL}$ ) and, in some cases, lower than the antibiotic gentamicin (E. coli, S. aureus, and E. faecalis). Moreover, the MIC of $\mathbf{1}$ for $S$. aureus is comparable with those of tulongicin and compound 11 (Figure 1) [22,23]. The effect of the chemical modification of $\mathbf{1}$ was then studied, all the derivatives 2-8 also share a DIM molecular unit with all the compounds reported in Figure 1. Removing the bromine atoms (compound 2) or the ethylamine side chain (compound 5), resulted in being detrimental for the antimicrobial activity with MICs greater than $128 \mu \mathrm{g} / \mathrm{mL}$ for all the tested microorganisms. On the contrary, the substitution of the bromine atoms with fluorines or the methylation of NHs (compounds 3 and 4, respectively), maintained the antimicrobial activity of the compounds against the tested microorganisms, even if with MICs values that are higher when compared to those of compound 1. To study the influence of an additional $N$-based heterocycle on the antimicrobial activity [22,28], an ethyl-azole side chain was introduced (compounds 6-8). Compounds 6 and 7, presenting an ethyl-pyrrole and -imidazole decoration, respectively, were not active as antimicrobial agents (MICs greater than $128 \mu \mathrm{g} / \mathrm{mL}$ ), while the bisindole-triazole conjugate 8 evidenced a moderate antimicrobial 
activity (MIC $128 \mu \mathrm{g} / \mathrm{mL}$ ). No significant difference in the antimicrobial activity of all the tested compounds emerged between gram positive and gram negative tested bacteria.

Subsequently, on the basis of their antimicrobial activity, the most active bisindoles were also investigated as an inhibitor of bacterial biofilm formation. It is well-known that bacteria organized in biofilm are more resistant to antimicrobials because the stratification of biofilm itself and the auto-produced matrix protect them from the action of antibiotics or disinfectants $[29,30]$. In our experiments, the lead compound 1 exhibited anti-biofilm activity against all the examined bacteria (biofilm formation inhibition greater than 50\%), at its MICs values, with the exception of K. pneumoniae $6 / 4$ (only $40 \%$ ). When tested at $2 \times$ MIC values, 1 resulted to be bactericidal against all the microorganisms, reaching $83.7 \%$ of biofilm formation inhibition in the case of K. pneumoniae 6/4. Interestingly, no inhibition was observed with 1 toward P. aeruginosa ATCC 9027 biofilm, both at MIC and $2 \times$ MIC values, pointing out the well-known resistance of this microorganism to antimicrobials [31,32]. The selected derivatives $(3,4$ and 8$)$ were also able to inhibit the biofilm formation of most of the examined microorganisms at their MIC values, with the exclusion of P. aeruginosa ATCC 9027. In detail, compound 3 (fluorine atoms instead of bromines) showed high anti-biofilm activity against $E$. coli ATCC 35218, reaching $97.6 \%$ of biofilm formation inhibition at $64 \mu \mathrm{g} / \mathrm{mL}$ MIC value, but it was less active against C. albicans ATCC 10231 (34.6\% of inhibition at $128 \mu \mathrm{g} / \mathrm{mL}$ ). Similarly, compounds 4 (NHs methylated) and 8 (bisindole-triazole conjugate) were active against K. pneumoniae 6/4, with percentages of biofilm formation inhibition of $64.7 \%$ (at $64 \mu \mathrm{g} / \mathrm{mL}$ ) and $65.8 \%$ (at $128 \mu \mathrm{g} / \mathrm{mL}$ ), respectively (Table 2). In any case, all the synthetic derivatives (3, 4, and 8 ) were active at MIC values higher when compared to those of the lead compound, thus compound 1 resulted in the best performing one.

After determining the efficacy of our selected compounds on microbial biofilms formation, their eradication activity against already developed biofilms was assessed. In this case, the molecules were added for 30 minutes to different biofilms in order to quantify their disaggregating activity. Our findings evidenced that 1 significantly eradicated all the tested biofilms, while 3, 4, and 8 showed a variable degree of disaggregating activities dependent on the bacterial species. It can be noted that the biofilm disaggregating activity was not tightly correlated with the observed anti-bacterial activity (as decrease of cell viability) against the examined microbial targets. Regarding the SAR, the chemical modifications of compound $1 \mathrm{did}$ not improve disaggregating property against $E$. coli ATCC 35218 biofilms. In the case of S. aureus ATCC 43387 biofilms, the NHs methylation (compound 4) did not alter the anti-bioflm activity, which resulted in being similar to that of $\mathbf{1}$, while the other decorations originated compounds that were less active. Regarding biofilms formed by C. albicans ATCC 10231, the most active disaggregating agent resulted 3 presenting fluorines instead of bromines. Compound $\mathbf{8}$, having triazole moiety, showed similar anti-biofilm activity when compared to $\mathbf{1}$ against K. pneumoniae 6/4 and C. albicans ATCC 10231 biofilms. It can be observed that the presence of bromine and ethylamine sidechain is essential for the antibiofilm activity of examined compounds, as also reported by Bunders et al. [33] for similar compounds (flustramine derivatives) against E. coli biofilm. It is well-known that indole signaling is involved in the regulation of a number of bacterial behaviors, including antibiotic resistance, virulence, and biofilm formation [34]. In this study, the marine alkaloid $\mathbf{1}$ and its derivatives contain two units of indole, thus suggesting that the observed antibiofilm activity may result from a modulation of indole-based signaling pathways.

\section{Conclusions}

In conclusion, our data highlight the potential of the natural marine alkaloid 2,2-bis(6-bromo-3indolyl) ethylamine $\mathbf{1}$ as antimicrobial and anti-biofilm agent. The modifications of the lead compound 1 have evidenced that the presence of halogens and/or ethylamine side chain are important for the maintenance of both antimicrobial and anti-biofilm activities. On the contrary, the addition of azole moiety to $\mathbf{1}$ was not effective in terms of microbial biofilms interaction. To our knowledge, this is the first work reporting the anti-biofilm activity of a natural bisindole against a broad spectrum of 
microorganisms. Compound $\mathbf{1}$ has shown MIC values that are comparable with those of similar compounds sharing the DIM molecular unit. However, the compounds that were reported in this work were prepared following a safe, straightforward, and scalable synthesis, resulting in being cheaper than others of the same category [19-23]. Therefore, compound $\mathbf{1}$ and some of its derivatives could be proposed for sanitation applications of environmental surfaces (such as industrial equipment, abattoirs, processing surfaces). Further studies will be necessary to assess the molecular mechanism of the active compounds and their efficacy against bacterial biofilms that formed on different surfaces and against mixed-species biofilms.

Supplementary Materials: The following are available online at http:/ /www.mdpi.com/2076-2607/7/2/28/s1.

Author Contributions: Conceptualization, W.B. and R.C.; methodology, S.L., G.F., and R.C.; data curation, R.C. and S.L.; writing—original draft preparation, R.C. and S.L.; writing-review and editing, W.B., R.C. and S.L. Authorship must be limited to those who have contributed substantially to the work reported.

Funding: This research received no external funding.

Acknowledgments: The authors wish to thank Gilberto Spadoni (University of Urbino) for fruitful discussion. The authors also thank the University of Urbino for partially funding this research.

Conflicts of Interest: The authors declare no conflict of interest.

\section{References}

1. Flemming, H.C.; Wingender, J. The biofilm matrix. Nat. Rev. Microbiol. 2010, 8, 623-633. [CrossRef]

2. Hall-Stoodley, L.; Stoodley, P.; Kathju, S.; Høiby, N.; Moser, C.; Costerton, J.W.; Moter, A.; Bjarnsholt, T. Towards diagnostic guidelines for biofilm-associated infections. FEMS Immunol. Med. Microbiol. 2012, 65, 127-145. [CrossRef]

3. Donlan, R.M. Biofilms: Microbial life on surfaces. Emerg. Infect. Dis. 2002, 8, 881-890. [CrossRef]

4. Abdallah, M.; Benoliel, C.; Drider, D.; Dhulster, P.; Chihib, N.E. Biofilm formation and persistence on abiotic surfaces in the context of food and medical environments. Arch. Microbiol. 2014, 196, 453-472. [CrossRef]

5. Percival, S.L.; Thomas, J.G.; Williams, D.W. The world of microbiology and biofilmology. In Microbiology of Wounds; Percival, S.L., Cutting, K., Eds.; CRC Press, Taylor and Francis Group: Boca Raton, FL, USA, 2010; pp. 1-58. [CrossRef]

6. Kobayashi, J. Search for new bioactive marine natural products and application to drug development. Chem. Pharm. Bull. 2016, 64, 1079-1083. [CrossRef]

7. Golantsov, N.E.; Festa, A.A.; Karchava, A.V.; Yurovskaya, M.A. Marine indole alkaloids containing an 1-(indol-3-yl)ethane-1,2-diamine fragment. Chem. Heterocycl. Compd. 2013, 49, 203-225. [CrossRef]

8. Hitora, Y.; Takada, K.; Ise, Y.; Okada, S.; Matsunaga, S. Dragmacidins G and H bisindole alkaloids tethered by a guanidino ethylthiopyrazine moiety from a Lipastrotethya sp. marine sponge. J. Nat. Prod. 2016, 79, 2973-2976. [CrossRef]

9. Choppara, P.; Bethu, M.S.; Vara Prasad, Y.; Venkateswara Rao, J.; Uday Ranjan, T.J.; Siva Prasad, G.V.; Doradla, R.; Murthy, Y.L.N. Synthesis, characterization and cytotoxic investigations of novel bis(indole) analogues besides antimicrobial study. Arab. J. Chem. 2015. [CrossRef]

10. Melander, R.J.; Minvielle, M.J.; Melander, C. Controlling bacteria behavior with indole-containing natural products and derivatives. Tetrahedon 2014, 70, 6363-6372. [CrossRef]

11. Veale, C.G.L.; Davies-Coleman, M.T. Marine bi-, bis-, and trisindole alkaloids. In The Alkaloids; Elsevier: Amsterdam, The Netherlands, 2014; Chapter 1; Volume 73, pp. 1-64. [CrossRef]

12. Bifulco, G.; Bruno, I.; Riccio, R.; Lavayre, J.; Bourdy, G. Further brominated bis- and tris-indole alakaloids from the deep-water New Caledonian marine sponge. J. Nat. Prod. 1995, 58, 1254-1260. [CrossRef]

13. Fahy, E.; Potts, B.C.M.; Faulkner, D.J.; Smith, K. 6-Bromotryptamine derivatives from the Gulf of California tunicate Didemnum candidum. J. Nat. Prod. 1991, 54, 564-569. [CrossRef]

14. Alvarado, S.; Roberts, B.F.; Wright, A.E.; Chakrabarti, D. The bis(indolyl)imidazole alkaloid Nortopsentin A exhibits antiplasmodial activity. Antimicrob. Agents Chemother. 2013, 57, 2362-2364. [CrossRef] [PubMed]

15. Chakrabarti, D.; Wright, A. Anti-Malarial Compounds from Marine Natural Products. U.S. Patent 20140200226A1, 17 July 2014. 
16. Mari, M.; Tassoni, A.; Lucarini, S.; Fanelli, M.; Piersanti, G.; Spadoni, G. Brønsted acid catalyzed bisindolization of $\alpha$-amido acetals: Synthesis and anticancer activity of bis(indolyl)ethanamino derivatives. Eur. J. Org. Chem. 2014, 3822-3830. [CrossRef]

17. Salucci, S.; Burattini, S.; Buontempo, F.; Orsini, E.; Furiassi, L.; Mari, M.; Lucarini, L.; Martelli, A.M.; Falcieri, E. Marine bisindole alkaloid: A potential apoptotic inducer in human cancer cells. Eur. J. Histochem. 2018, 62, 7-12. [CrossRef] [PubMed]

18. Mantenuto, S.; Lucarini, S.; De Santi, M.; Piersanti, G.; Brandi, G.; Favi, G.; Mantellini, F. One-pot synthesis of biheterocycles based on indole and azole scaffolds using tryptamines and 1,2-diaza-1,3-dienes as building blocks. Eur. J. Org. Chem. 2016, 3193-3199. [CrossRef]

19. Ciulla, M.G.; Kumar, K. The natural and synthetic indole weaponry against bacteria. Tetrhedron Lett. 2018, 59, 3223-3233. [CrossRef]

20. Gillespie, D.E.; Brady, S.F.; Bettermann, A.D.; Cianciotto, N.P.; Liles, M.R.; Rondon, M.R.; Clardy, J.; Goodman, R.M.; Handelsman, J. Isolation of antibiotics turbomycin A and B from a metagenomic library of soil microbial DNA. Appl. Environ. Microbiol. 2002, 68, 4301-4306. [CrossRef]

21. Mandal, S.M.; Pegu, R.; Porto, W.F.; Franco, O.L.; Pratihar, S. Novel boronic acid derivatives of bis(indolyl) methane as anti-MRSA agents. Bioorg. Med. Chem. Lett. 2017, 27, 2135-2138. [CrossRef]

22. Liu, H.B.; Lauro, G.; O'Connor, R.D.; Lohith, K.; Kelly, M.; Colin, P.; Bifulco, G.; Bewley, C.A. Tulongicin, an antibacterial tri-indole alkaloid from a deep-water Topsentia sp. sponge. J. Nat. Prod. 2017, 80, 2556-2560. [CrossRef]

23. Dong, Y.; Lushnikova, T.; Golla, R.M.; Wang, X.; Wang, G. Small molecule mimics of DFTamP1, a database designed anti-Staphylococcal peptide. Bioorg. Med. Chem. 2017, 25, 864-869. [CrossRef]

24. Campana, R.; Casettari, L.; Fagioli, L.; Cespi, M.; Bonacucina, G.; Baffone, W. Activity of essential oil-based microemulsions against Staphylococcus aureus biofilms developed on stainless steel surface in different culture media and growth conditions. Int. J. Food Microbiol. 2017, 241, 132-140. [CrossRef]

25. Sun, J.; Wu, J.; An, B.; Voogd, N.J.; Cheng, W.; Lin, W. Bromopyrrole alkaloids with the inhibitory effects against the biofilm formation of Gram negative bacteria. Mar. Drugs 2018, 16, 1-15. [CrossRef] [PubMed]

26. Tanaka, N.; Kusama, T.; Kashiwada, Y.; Kobayashi, J. Bromopyrrole alkaloids from Okinawan marine sponges Agelas spp. Chem. Pharm. Bull. 2016, 64, 691-694. [CrossRef] [PubMed]

27. Hodnik, Ž.; Łoś, J.M.; Žula, A.; Zidar, N.; Jakopin, Ž.; Łoś, M.; Sollner Dolenc, M.; Ilaš, J.; Weggrzyn, G.; Peterlin Mašič, L.; et al. Inhibition of biofilm formation by conformationally constrained indole-based analogues of the marine alkaloid oroidin. Bioorg. Med. Chem. Lett. 2014, 24, 2530-2534. [CrossRef] [PubMed]

28. Minvielle, M.J.; Bunders, C.A.; Melander, C. Indole/triazole conjugates are selective inhibitors and inducers of bacterial biofilms. Med. Chem. Commun. 2013, 4, 916-919. [CrossRef] [PubMed]

29. Hall-Stoodley, L.; Costerton, J.W.; Stoodley, P. Bacterial biofilms: From the natural environment to infectious diseases. Nat. Rev. Microbiol. 2004, 2, 95-108. [CrossRef]

30. Richards, J.J.; Melander, C. Controlling bacterial biofilms. Chembiochem 2009, 10, 2287-2294. [CrossRef] [PubMed]

31. El Zowalaty, M.E.; Al Thani, A.A.; Webster, T.J.; El Zowalaty, A.E.; Schweizer, H.P.; Nasrallah, G.K.; Marei, H.E.; Ashour, H.M. Pseudomonas aeruginosa: Arsenal of resistance mechanisms, decades of changing resistance profiles, and future antimicrobial therapies. Future Microbiol. 2015, 10, 1683-1706. [CrossRef]

32. Masák, J.; Čejková, A.; Schreiberová, O.; Rezanka, T. Pseudomonas biofilms: Possibilities of their control. FEMS Microbiol. Ecol. 2014, 89,1-14. [CrossRef] [PubMed]

33. Bunders, C.A.; Minvielle, M.J.; Worthington, R.J.; Ortiz, M.; Cavanagh, J.; Melander, C. Intercepting bacterial indole signaling with flustramine derivatives. J. Am. Chem. Soc. 2011, 133, 20160-20163. [CrossRef]

34. Worthington, R.J.; Richards, J.J.; Melander, C. Small molecule control of bacterial biofilms. Org. Biomol. Chem. 2012, 10, 7457-7474. [CrossRef] [PubMed]

(C) 2019 by the authors. Licensee MDPI, Basel, Switzerland. This article is an open access article distributed under the terms and conditions of the Creative Commons Attribution (CC BY) license (http:/ / creativecommons.org/licenses/by/4.0/). 